\title{
DIE VERBAND TUSSEN WAARGENOME LEIERSKAP EN DIE VLAK VAN OUTONOMIE BINNE SPANVERBAND
}

\author{
A VAN DER HEYDE \\ GERT ROODT \\ Program in Bedryfsielkunde \\ Departement Menslikehulpbronbestuur \\ Randse Afrikaanse Universiteit
}

\begin{abstract}
The relationship between perceived leadership and the level of outonomy in a team context remains a contemporary theme in the work environment and seemingly has a substantial influence on organisational success. This study attempted to ascertain the relationship between leadership and the level of outonomy in a team context. Two hundred and thirty $(\mathrm{N}=230)$ individuals, grouped into 56 teams from four South African companies participated in the study. The superordinate's leadership style as well as the level of outonomy in the specific group was measured. Apart from the useful information obtained in comparison with international research, especially in terms of leadership data, the study did conclusively point out a significant correlation between leadership style and outonomy in team context.
\end{abstract}

\section{OPSOMMING}

Leierskap en selfgerigte spanfunksionering bly kontemporêre temas in die bedryfsmilieu, wat oënskynlik organisasiesukses wesenlik kan beinvloed. Die doel van hierdie studie was om die waargenome verband tussen leierskap en die vlak van outonomie binne spanverband te bepaal. Tweehondered-en-dertig ( $\mathrm{N}=230)$ individue, gegroepeer in 56 spanne vanuit vier Suid-Afrikaanse maatksappye het aan die studie deelgeneem. 'n Meting van sowel die bogeskikte se leierskapstyl en die vlak van outonomie binne spanverband is verkry. Afgesien van bruikbare inligting rondom veral die leierskapdata in vergelyking met internasionale navorsing, het die studie ' $n$ beduidende verband tussen leierskapstyl en outonomie binne spanverband uitgewys.

\section{SYNOPSIS}

South African managers are facing a tremendous management/ leadership challenge owing to a changing and more competitive business context. Various theoretical models exist that try to capture the complexities of leadership behaviour. Leadership literature is dominated to some extent by the work of Bass and associates that conceptualise leadership behaviour consisting of two dominant styles, namely transactional and transformational leadership. Leadership theories of other researchers like that of Manz and Sims (1991) propose a broader view of leadership consisting of four different styles. It was decided to use Manz and Sims' instrument to assess leadership styles for this study, because it would capture a wider spread of leadership behaviours. South African leaders were traditionally more autocratic and this instrument posed the potential to assess the degree of movement towards more democratic leadership styles.

The use of autonomous work teams in South African industries is still a fairly recent development. Although it offers huge benefits in terms of employee motivation and empowerment, it poses equal challenges in terms of leadership and management. Using autonomous work teams, basically enforces a new and more democratic leadership and management approach. The question that arises, is to what extent a more empowering leadership style is associated with a larger degree of autonomy in work teams.

The methodology followed in this study was to survey 230 employees of 56 leaders in four different organisations. Leadership styles of these team leaders were assessed with the 81 item leadership questionnaire of Manz and Sims (1991) and the degree of autonomy of the team was assessed with the 35 item autonomy questionnaire of Gullowsen (1979). The questionnaires were distributed through the different human resource management departments of the different organisations. Participation was voluntary, confidential and anonymous.

The responses on the two instruments were first factor analysed, using a procedure suggested by Schepers (1992), followed by an

Versoeke vir afskrifte moet gerig word aan: A van der Heyde, Departement, Menslikehulpbronbestuur, RAU Universiteit, Posbus 524, Auckland Park, 2006 iterative item analysis. Both the leadership questionnaire and the autonomy questionnaire yielded two scales with acceptable internal reliabilities (Cronbach Alphas). The canonical correlations between the two leadership and the two autonomy variables indicated that that a more participating and empowering leadership style was significantly associated with higher levels of autonomy. No other canonical variates were abstracted that could explain a significant amount of variance in the equation.

Results of this study suggest that teams included in this study are not functioning on a fully autonomous base yet. Concommitantly, the leadership styles applied in these teams should also be moved towards a more empowering and transformational style.

Die deursnee Suid-Afrikaanse organisasie beleef die voorspelde uitdagings wat meegebring is deur internasionale mededinging onder andere verhoging in arbeid-, kapitaal-, en bateproduktiwiteit te midde van 'n milieu van kompleksiteit, vinnige aanpassing en struktuurlose chaos. Besigheidsleiers moet hierbinne kognitiewe, situasionele en normatiewe dissonansie verwerk en bestuur, ten einde aan aandeelhouers en verwante belangegroepe se verwagtings te voldoen. Enersyds word ' $n$ gewag gemaak van bemagtingingsbestuur en selfgerigte spanfunksionering, terwyl daar andersyds verwag word dat leiers op transaksionele en dikwels direktiewe/outokratiese wyse finansiële resultate moet bereik. Voeg hierby die vlaag besigheidsherposisionerings, -samevoegings en -oornames, waarbinne die gemiddelde bestuurder en werknemer as bate oorgeneem, herontplooi en/of afgeskaal word, en dit verteenwoordig allermins die noodsaaklike fondament tot wêreldklasleierskap en spanfunksionering.

Die doel van hierdie studie is om die verhouding tussen die vlak van selfgerigte leierskap en outonomie, soos dit binne spanverband ervaar word, te ondersoek. Die studie is verkennend en teoriebouend van aard en is geensins daarop gefokus om ' $n$ finale en enkelvoudige leierskapmodel tot outonome groepfunksionering daar te stel nie. As vertrekpunt word 'n historiese perspektief rondom kritiese leierskapsteorieë aangebied, wat as basis dien vir die daarstel en evaluering van breë leierskaptipes, waarteen die navorsingsresultate gespieël 
word. Gegewe die aanname rondom die evolusionêre aard in die ontwikkeling van leierskapstyle is spesifiek besluit op Manz en Sims se vierstyl leierskapnavorsing en meegaande leierskapsvraelys. Die deursnee Suid-Afrikaanse bestuurder word allerweë as meer outokraties en voorskriftelik geag en is dit beplan om ' $n$ meting wyer as die klassieke leierskapsgroepering in transaksionele en transformasionele style te verkry.

Ten aanvang word ' $\mathrm{n}$ uiteensetting van die konsepte en teoretiese fundering van transaksionele en transformasionele leierskap, asook Manz en Sims (1991) se leiers-argetipes, naamlik "Strongman", "Transactional Leader", "Visionary Hero" en "Super Leader" (Empowering Leadership), gebied. Insgelyks word ' $\mathrm{n}$ teoretiese oorsig rondom die wese en basis van selfgerigte spanfunksionering voorgehou waarbinne die rol en funksie van die spanleier van selfgerigte spanne pertinent aandag geniet.

Die onderskeid tussen transaksionele en transformasionele leierskapsgedrag word ten beste toegelig deur die kontrastering van die twee style. Burns (1978) het die transaksionele bestuurder beskryf as iemand wat fokus op ' $\mathrm{n}$ beloningverhouding met die oog op wedersydse uitruiling, teenoor die transformasionele leier wat die transformering van die volgelinge se emosionele staat vanaf onmiddellike laerorde behoeftes tot vervulling en selfaktualisering as oogmerk het.

Tichy en Ulrich (1984) het na die transformasionele leier verwys as instrumenteel in die daarstelling van ' $n$ toekomsrigting, die motivering van ondergeskiktes om die visie te aanvaar en na te streef en oor tyd in die vorm van werkwyses en roetines te verpraktiseer. Hierdie siening strook met die leierskapnavorsing van Mahoney (1993), wat aanvanklik suksesvolle bestuursgedrag opgeteken en in vraelysvorm saamgevat het, maar tydens die tagtigerjare die model vanaf bestuursdoeltreffendheid na leierskapdoeltreffendheid moes aanpas, hoofsaaklik vanweë die toenemende komplekse vereistes wat deur organisasies op die bestuurder/leier geplaas is. Volgens Mahoney (1993) word die leier se rol beskryf as ontwikkeling van ' $n$ visie vir die organisasie, oorreding van andere tot navolging van sodanige visie en die suksesvolle implementering daarvan deur die vaardige aanwending van leierskap en bestuurspraktyke. (Die vervlegde aard tussen transaksionele en transformasionele leiersgerag word dus uitgebeeld). Soos Bennis en Nanus (1985) en Charlton (1993) het Mahoney (1993) die konsepte 'bestuur' en 'leierskap' gekontrasteer tot twee bewese breë leierskapstyle wat die transaksionele teenoor transformasionele bestuurs/leierskapskomponente stel. Bestuur word as ' $n$ proses geag wat ten doel het om organisasieresultate met en deur mense te bereik met die fokus hoofsaaklik op posisionele mag en die proses van kontraktuele uitruiling van resultate en beloning tussen bestuurder en ondergeskikte.

Hierteenoor behels leierskap ' $\mathrm{n}$ meer omvattende konsep wat die bereiking van organisasiedoelwitte insluit. Dit word bereik deur ' $n$ proses van inspirasie, beïnvloeding en skep van entoesiasme deur die skep van ' $n$ visie en die daarstel van standhoudende verhoudinge, gekenmerk deur vertroue, samewerking en oortuiging. Bass (1990) het die voorgaande konsep ondersteun deur transformasionele leierskapgedrag te omskryf as die skep van inspirerende doelwitte; versterking van die visie deur die gebruik van beelde en simbole; verduideliking van taakdoelwit; kommunikasie van positiewe uitkomste en vertroue in volgelinge dat hulle suksesvol sal wees hoofsaaklik deur beklemtoning van emosie, visualisering van die einddoel en aanduiding van metodiek tot einddoelbereiking.

Kotter (1990) het verder hierop uitgebrei en verwys eweneens na die interverwantskap tussen die konsepte "leierskap" en "bestuur" in die effektiewe bereiking van resultate. Hy het ' $n$ dualistiese benadering voorgestel sonder voorkeur vir enige van die twee style en kategoriseer die verweefde funksies soos volg:
TABEL 1

\section{LEIERSK AP VERSUS BESTUUR}

\begin{tabular}{ll}
\hline Bestuur & Leierskap \\
\hline Fokus op bestuur van kompleksiteit & Fokus op bestuur van verandering \\
Beplanning en begroting & Neerlê van toekosmrigting \\
Organisering en bemanning & Belyning van mense \\
Kontrole en probleemoplossing & Motivering en inspirasie \\
\hline
\end{tabular}

Uit voorgaande breë funksies van bestuur en leierskap blyk die aanvullende aard daarvan instrumenteel te wees vir organisasiesukses. Afleidend word die aanname dus gehuldig dat beide transaksionele en transformasionele leierskap as bewese argetipes aanvaar was vanweë die groepering van spesifieke fundamentele leiergedrag. Sodanige groepering kan wel as ' $n$ growwe gaffelsplitsing beskryf word vanweë die sterk teoretiese versus empiriese fundering. Yukl (1989, p. 212) het hierteen gewaarsku dat "... the distinction between the two types of leadership is not as clear as some theorists would have us believe ... these differences should be determined by empirical research, not predetermined theoretical definitions that make unnecessary assumptions and bias subsequent research". Sashkin en Rosenbach (1992, p. 17) het die vraag gevra: "is it possible, then that what we have called transformational leadership could be re-interpreted within the traditional paradigm of transaction and exchange?" Bass en Avolio (1993, p. 76) het na deeglike besinning oor historiese perspektiewe en navorsing aangevoer dat: "we invite critics and supporters alike to join in the effort to shape a theory and model of leadership that captures a broader array of leadership behaviours and attributes than previously studied".

Voorgaande bewustheid ondersteun Mahoney (1990) en Sims en Cox (1995) se siening dat die sosiale en ekonomiese konteks van organisasieleierskap so vinning en betekenisvol verander dat ' $n$ voortdurende herdefiniëring van gevraagde bevoegdhede noodsaaklik blyk te wees. Die klem op internasionele mededinging, deurbraakverbeterings, bemagtiging, strategiese fokus en selfgerigte spanwerk ondersteun hierdie aanname.

Bass en medewerkers (1993) asook Manz en Sims (1991) se leierskapnavorsing het bostaande aanname ondersteun met die daarstel van ' $n$ vier (4) argetipe leierskapmodel, te wete die "direktiewe", "transaksionele", "transformasionele" en "bemagtigings-" leiergedragsmodel. Vervolgens word 'n bondige uiteensetting verskaf van die teoretiese onderbou verteenwoordigend tot elke argetipe wat as basis gedien het in die samestelling van die leierskapvraelys soos wat in die onderhawige studie gebruik is.

\section{Direktiewe leierskap}

Die outokratiese leier maak op posisionele en intimiderende mag staat om ondergeskiktes te mobiliseer (French \& Raven, 1995). Hierdie argetipe vind sy oorsprong in die Teorie X-bestuurstyl (McGregor, 1960), die Ohio studies (Fleishman, 1973), Michigan studies (Bass, 1967) en die sogenaamde "Punishment" navorsing (Arvey \& Ivancevich, 1980).

Die onderliggende temas, voortspruitend uit genoemde navorsing, het merendeels op voorskriftelike en outokratiese bestuur gefokus met 'n sterk klem op straf/teregwysing vir niekonformering tot neergelegde doelwitte. Bostaande styl verg dus 'n outoritêre en voorskriftelike bestuurstyl, gerugsteun deur streng beheermeganismes.

Samevattend is direktiewe leiersgedrag dus gebou op instruksie en beheer, toegekende doelwitte, toevallige teregwysing, intimidasie en nie-toevallige teregwysing (Pearce, 1995). 


\section{Transaksionele leierskap}

Teorieë relevant tot hierdie argetipe sluit in die Verwagtingsteorie (Vroom, 1964) "Pad-doel"-teorie (House, 1971) Uitruilteorie (Adams, 1963; Homans, 1958; Homans, 1961) en Versterkingsteorie (Luthans \& Kreitner, 1985) in.

Hierdie teorieë het deurentyd op die manipulering van gewensde gedrag op ' $n$ transaksie-basis gefokus en word deur die werknemer geëvalueer aan die beloning teenoor poging aangewend. Die toerieë verteenwoordig ' $n$ wesentlike leierskapsargetipe met materiële en persoonlike erkenning/beloning as basis (Pearce, 1995).

\section{Transformasionele leierskap}

Hierdie leierskapsargetipe het sy oorsprong te danke aan die Charisma Sosiologie (Weber 1924, 1946, 1947), die charismatiese leierskapsteorie (House, 1977) en transformasionele leierskapsteorieë.

Die wese van die relevante teorieë is gesetel in die impak van die leier, as resultaat van unieke interpersoonlike vaardighede en die effek daarvan op ondergeskiktes se gedrag.

Transformasionele leierskap was as bewese argetipe voorgehou met tiperende gedrag soos stimulering en inspirering van volgelinge, visiegedrewendheid, idealisme en die bevraagtekening van die status-quo (Pearce 1995).

\section{Bemagtigingsleierskap}

Die onderliggende teoretiese fundering van Bemagtigingsleierskap vind sy oorsprong in Thorenson en Mahoney (1974) se Gedragselfbestuurteorie, Bandura (1986) se Sosiaalkognitiewe leerteorie, die Kognitiewe Gedragsmodifiseringsnavorsing van Erez \& Arad (1986) en Meichenbaum (1977) se Deelnemende Doelwitstellingnavorsing.

Bemagtigingsteorieë het die era van selfbestuur ingelei met die klem op aanspreeklikheid vir resultate. Die leier dien op dié basis as rolmodel en fasiliteerder eerder as bestuurder. Bemagtigingsleierskap vind dus neerslag in gedrag soos aanmoediging van: positiewe geleentheidsdenke, selfbeloning, selfleierskap, deelnemende doelwitstelling en spanwerk. Selfgerigte werkspanne bied die konteks waar hierdie leierskapsvaardighede ontwikkel kan word.

\section{Selfgerigte werkspanne (SGWS)}

Teen die agtergrond van die teoretiese ontwikkeling van leierskapsargetipes, word die aanname voorgehou dat transformasionele en bemagtigingsleierskap kritiese leierskapsgedrag binne selfgerigte werkspanne is. Gevolglik word 'n oorsig rondom selfgerigte werkspanne gebied, ten einde verlangde leierskapsdimensies af te lei.

\section{Definisie en eienskappe van SGWS}

Fisher (1993) het SGWS beskryf as: "A group of employees who have a day to day responsibility for managing themselves and the work they do with a minimum of direct supervision. Members of the self directed teams typically handle job assignments, plan and schedule work, make production and/or service related decisions, and take action on problems" (p. 15).

Pasmore en Mlot (1994) het die konsep SGWS beskryf as: "A stable, multiskilled, multi functional group with responsibility for the completion of a relatively whole piece of work and the control of all input, output, and supporting variables and conditions that influence team performance" (p. 16).

Gebaseer op navorsing en uitgebreide ervaring het Wellin et al. (1991) selfgerigte werkspanne omskryf as: "An intact group of employees who are responsible for a "whole" work process or segment that delivers a product or service to an internal or external customer. To varying degrees, team members work together to improve their operations, handle day to day problems, and plan to control their work" (p. 3).
Samevattend uit genoemde definisies kan SGWS beskryf word as ' $\mathrm{n}$ permanente self besturende groep interafhanklike persone wat op gereelde basis met mekaar in interaksie verkeer, wat beheer uitoefen oor "n totale ("whole") werksproses en gedifferensieerde bydraes maak tot bereiking van ' $n$ gemeenskaplike doel. (Walton \& Hackman, 1986). Die klem op selfbestuur blyk duidelik ' $\mathrm{n}$ sterk fokus binne die raamwerk van SGWS te wees.

\section{Die konseptuele basis van SGWS}

Sinonieme begrippe vir die konsep SGWS sluit in: selfbesturende, outonome, semi- outonome, selfleidende, selfontwerpte, hoë prestasie- of hoë betrokkenheid- werkspanne.

Die konsep SGWS het sy oorsprong in die Sosio-Tegniese Sisteemteorie wat deur Eric Trist by die Tavistock Instituut ontwikkel is. Die basis van die teorie is dat die kern van organisasie- effektiwiteit bepaal word deur gesamentlike optimalisering van beide die sosiale en tegniese komponente. Sodanige optimalisering is ' $\mathrm{n}$ voorvereiste vir ' $\mathrm{n}$ sisteem wat produktief moet wees en wat werknemerbehoeftebevrediging aanspreek (Cummings, 1987; Pearce \& Ramlin, 1987). Outonomie verteenwoordig die sentrale konsep in die SosioTegniese Sisteemteorie (STST). Die volgende kenmerke word geïdentifiseer as STST in werksontwerp:

- 'n relatiewe geheelwerksproses

- groepslede wat oor 'n verskeidenheid vaardighede beskik relevant tot die groeptaak

- werknemerdiskresie in besluitneming oor byvoorbeeld metode van werk, taak skedulering en delegering van take aan lede, erkenning en terugvoer vir die groep as geheel (Cummings, 1987; Pearce \& Ramlin, 1987).

Genoemde attribute van selfregulering vorm die kern tot die groep se grensafbakening, outonomie en terugvoer en is noodsaaklik om afwykings tot groepdoelbereiking te beheer. Die basis van die outonomie-konsep is die mate waartoe groepslede beheer het of besluite kan neem aangaande faktore binne hul werksomgewing.

\section{Sleutelfaktore tot suksesvolle SGWS}

Die ontwerp van SGWS is volgens Cummings (1987) op drie sleutelfaktore gegrond, naamlik taakdifferensiasie, grensbeheer en taakbeheer. Al drie faktore het ' $\mathrm{n}$ impak op die wyse waarop samewerking in die span geskied asook op die beheer van afwykings tot groepdoelwitbereiking. Vervolgens volg ' $\mathrm{n}$ bespreking van die belangrikste faktore.

Taakdifferensiasie verwys na die mate waartoe die groep se taak opsigself outonoom is, betekenisvol is en dus ' $n$ geheelproses vorm. Grensbeheerfaktore behels die mate waartoe werknemers hul taakomgewing kan beïnvloed. Taakbeheer omsluit die proses van byvoorbeeld omskakeling van roumateriale tot die eindproduk in ' $n$ produksiekonteks.

In meer kontemporêre vorm verwys Veldsman (1994) na die sleutelonderskeidende aard van SGWS as die aard van die span se kerntaak en die mate van outonomie waaroor die span tot die taak beskik. Hy gaan voort deur na die kerndimensies van betrokkenheid, bemagtiging, instaatstelling en leierskap te verwys en dui op die interverwantskap en evolusionêre aard daarvan. Betrokkenheid verwys na die mate van vryheid wat toegeken word aan organisasielede om die potensiële taak waaroor die span beheer kan neem te bestuur en wat bydra tot die skepping en onderhouding van gunstige spanprestasietoestande in verhouding tot die span se taak. Weereens dui dit op 'n potensiële sterk konnotasie met selfbestuur as bemagtigingsleierskaptipe.

Die evolusionêre aard van SGWS

Verskeie outeurs, onder andere Fisher (1993), Glaser (1992), Gullowsen (1979), Pasmore en Mlot (1994) en Veldsman (1994) het pertinent melding gemaak van die fases van ontwikkeling 
waardeur 'n span gelei word tot volle outonomie. Vyf fases van ontwikkeling kan op ' $n$ kontinuum van betrokkenheid onderskei word en sluit in: ander-gerigtheid, semi-deelnemend, deelnemend, semi-outonoom en outonoom.

Gullowsen (1971) het sewe kriteria ontwikkel, waaraan 'n SGWS moet voldoen, alvorens op volle outonomie of totale selfbestuur aanspraak gemaak kan word. Die sewe kriteria sluit in:

- Die span beïnvloed kwalitatiewe asook kwantitatiewe faktore tot doelbereiking. Kwalitatiewe faktore behels die groep se uitset op produksie, terwyl kwantitatiewe faktore die volume van werk verteenwoordig.

- Die outonome span beheer sy eie prestasie, byvoorbeeld wanneer die groep wil werk en hoe aspekte soos oortyd-werk aangespreek word.

- Die outonome span neem self besluite rondom die produksiemetode.

- Die outonome groep besluit self hoe take tussen lede versprei word.

- Groeplidmaatskap deur keuring en indiensneming van nuwe lede word deur die span hanteer.

- Die outonome groep besluit self oor die aanstelling van die spanleier.

- Lede van outonome groepe besluit hoe individuele take uitgevoer word.

Die SGWS-leier en ontluikende dilemma rondom 'n nuwe leierskapstyl

Die kern van die tradisionele leierskaprol is om binne ' $\mathrm{n}$ outokratiese, direktiewe stelsel orde te skep, beheer uit te oefen en effektiwiteit deur die aanwending van die werksmag te verseker. In die suiwerste vorm kan bestuur terug herlei word na Frederick W. Taylor se wetenskaplike bestuursbenadering. Bestuur se metodes om beheer uit te oefen het gemanifesteer in 'n hierargie van gespesialiseerde rolle wat " $n$ "topdown". benadering in gesagtoekenning tot gevolg het en neerslag gevind het in statussimbole gekoppel aan hiërargiese posisie (Walton, 1985)

Uit onlangse navorsing blyk dit dat bykans $80 \%$ van tradisionele toesighouers van mening is dat hul rol dramaties gaan verander gegewe die noodsaaklikheid van SGWS. Studente in die bestuurswetenskappe, soos Drucker en Demming (soos aangehaal deur Fisher, 1993), het albei voorspel dat die toekomsrol en -funksie van die bestaande toesighouer radikaal gaan verander. Demming het selfs beweer dat die bestaande bestuursisteem die mens vernietig en dat die mens derhalwe sal moet aanpas ten einde nog ' $n$ volwaardige rol te speel (Fisher, 1993).

Die bestaande toesighouer is tradisioneel op grond van tegnies/vakkundige kennis en prestasie bevorder met die primêre taak om besluite te neem, individuele werknemers of spanne te beheer en te sorg dat optrede en aktiwiteite binne bestaande neergelegde prosedures en regulasies uitgevoer word.

Die woorde van ' $\mathrm{n}$ tradisionele toesighouer se ontnugtering met die implementering van SGWS spreek boekdele: “... the very things that brought me success - my centralized control, my aggressive behaviour, my authoritarian business practices - were creating the environment that made me so unhappy" (Wellins, et al., 1991, p. 128).

Fisher (1993, p.46) het verder opgemerk: "One of the most difficult changes to make when implementing high performance systems is for the 'manager' to become the 'leader' ... they have been promoted, recognized and rewarded for their controlling skills, not their delegation, coaching and facilitation skills".

Bostaande aanhalings verteenwoordig in die eerste plek die verwagte nuwe rol gekoppel aan die spanleier, terwyl dit insgelyks dui op die konflik verbonde aan die transformasieproses vanaf tradisionele spanleier na SGWS-leier.
Die aanname word wyd gehuldig dat dit moeiliker is vir die spanleier om by SGWS aan te pas as vir die spanlede.

Binne die konteks van SGWS kan leierskap gedefinieer word as daardie aktiwiteite wat bydra tot die daarstelling en instandhouding van gunstige spanprestasietoestande binne die bestek van die span se kerntaak (Cummings, 1978; Fisher, 1993; Pasmore, 1988; Wellis et al, 1991).

Hiernaas kan twee breë leierskapdimensies onderskei word, naamlik:

- Instaatstelling as fasilitering van verlangde bevoegdhede en gedrag in spanlede en die versekerde gebruik daarvan.

- Bemagtiging as versterking van die span se moontlikheid tot sukses deur die vermindering van die span se kerntaak onsekerheid (intern) sowel as die span se kontekstuele onsekerheid (ekstern).

Fisher (1993, p. 123) het die die rol van die spanleier binne selfgerigtewerkspanne soos volg beskryf:

- Die span is verantwoordelik vir die dag tot dag bestuur van die deursetprosesse.

- Die leier is verantwoordelik vir die bestuur van die omgewing waarbinne die span funksioneer soos byvoorbeeld skakeling met kliënte en ander spanne.

- Dit is die leier se rol om te verseker dat die span suksesvol tot die omgewing aanpas, wat dui op die rol as organisasieontwerper, infrastruktuurbouer en interorganisasie skakelpersoon. Spanlede funksioneer dus binne die stelsel, terwyl die SGWS-leier 'n diens tot die stelsel lewer byvoorbeeld vergoedingsbestuur, terugvoerverskaffing en opleidingkoördinering.

- Die leier se funksie is om 'n inspirerende visie te skep en die span aan te moedig tot nastrewing daarvan.

- Die spanleier moet as ' $n$ rolmodel optree deur die verlangde gedrag vir spanlede en die leier te openbaar.

- Vir die span om binne die stelsel optimaal te funksioneer moet die spanleier lede oplei en afrig om hul volle potensiaal te bereik.

- As besigheidsontleder moet die spanleier die omgewing ontleed en interpreteer ten einde die span te lei tot verandering in gedrag.

- Die spanleier is verder verantwoordelik vir voortdurende bevraagtekening van die status quo en om struikelblokke in die pad van spanprestasie uit die weg te ruim.

- As fasiliteerder moet die spanleier verseker dat die nodige toerusting, inligting en hulpbronne beskikbaar is vir optimale groepsprestasie.

- Deur die kliënteskakelingsrol moet die spanleier goeie kliënteverhoudinge handhaaf, bewus wees van hul behoeftes en prioriteite bepaal volgens kliëntbehoeftes.

Daar is dus ' $\mathrm{n}$ duidelike ooreenkoms tussen die rol van die spanleier en gedrag, soos onder die transformasionele en bemagtigingsleierskaptipes gepostuleer is. Manz en Sims (1990) het soortgelyke SGWS-leierskapsgedrag gepostuleer uit navorsing en bestudering van die Selfbestuurteorie, SosioTegniese en Outonome Werksgroepteorie.

Selfbestuurteorie: Groeplede word aangemoedig om selfversterkend op te tree met betrekking tot hoë vlak groepprestasie, om selfkritiserend op te tree jeens lae prestasie, om selfprestasie-doelwitte te stel, om prestasievlakke te monitor en te evalueer, om hoë verwagtinge te handhaaf met betrekking tot groepprestasie en om 'n aktiwiteit eers te deurdink voordat dit uitgevoer word.

Sosio-Tegniese en Outonome Werksgroepteorie: Groeplede fokus op interafhanklike samewerking, fasilitering van hulpbronne, opleiding en spanlede, fasilitering van probleemoplossingsprosesse, erkenning, aanspreek van sub-standaard prestasie en meting van prestasiedoelwitte. 
In hul navorsing rondom selfbesturende leierskap, het Sims et al. (in Pearce, 1995) verwys na bemagtigingsleierskap, ook bekend as Super-leierskap, as die aangewese leierskap argetipe tot selfbestuur. Die bydraende denkrigtings tot hierdie konsep sluit in:

- Gedragselfbestuur, wat selfwaarneming, selfdoelwitstelling, selferkenning, selfberisping, omgewingsinterpretasie en -inoefening insluit.

- Sosiaal-Kognitiewe Teorie - hiervolgens neem die spanlid die leier se gemodelleerde selfleierskapgedrag aan.

- Kognitiewe gedragmodifisering - volgens dié denkskool word konseptuele gebeure of probleme doelgerig tot geleenthede tot leer omskep en versterk dus die bemagtigingsoriëntasie.

- Deelnemende doelwitstelling - dit dui op die voordele wat deelname in doelwitstelling inhou tot die ontwikkeling van selfbestuurgedrag by ondergeskiktes.

Uit die genoemde leiersgedragrolle blyk dit dat die spanlede ' $\mathrm{n}$ verskeidenheid tradisionele leiersrolle self kan vervul en dat die spanleier se rol meer dié is van rolmodel, aanmoediging en afrigting tot selfbestuur en prestasieverbetering. Die ontplooiing van die leierskapgedragsrolle vind uiteraard ook evolusionêr plaas en gaan gepaard met die span se groeiproses na ' $n$ volwaardige outonome span.

Die aanvanklike transaksionele en transformasionele leierskapstipes is ooreenkomstig individuele en groepbevryding na ' $n$ groter mate van bemagtiging en selfbestuur omvorm. Die teoretiese begronding vir sodanige leierskapevolusieproses is voorgehou, terwyl daar insgelyks op ontwikkeling van selfgerigte spanne en die veranderende rol van die spanleier gefokus is. Deurgaans is die oënskynlike verband tussen leierskapsgedragsvorme ooreenkomstig die bemagtigings- en selfbestuurteorieë en die spanevolusieproses tot ' $\mathrm{n}$ groter mate van selfbestuur binne die selfgerigte span uitgewys. Beide die leierskapsteorieë asook die selfgerigte spanteorieë wys op die evolusionêre aard van die ontwikkelingsproses en word derhalwe gekoppel aan sosiale sowel as ekonomiese ontwikkelingstendense. Hierby beleef die bestaande spanleier ' $n$ identiteitskrisis met betrekking tot versoening van uitset-tenalle-koste versus ontwikkeling en bemagtiging van groeplede tot 'n groter mate van selfbestuur, terwyl hy steeds verantwoordelik bly vir genoemde uitsette. Daar bestaan dus 'n sterk verwagting dat die verband tussen spesifieke leiergedrag met die vlak van outonomie binne spanverband sal korreleer en ook laasgenoemde sal bevorder. Uiteraard geld die teendeel ook, naamlik dat outokratiese bestuursgedrag tot ' $n$ beperkte ontwikkeling van outonomie binne spanverband sal lei.

Met voorgaande teoretiese onderbou en probleemstelling kan die studiedoelwitte tweeledig voorgehou word. Eerstens was die kategorisering rondom leierskapstyle, soos dit spesifiek deur Manz en Sims (1991) voorgestel is, getoets aan die hand van die studiebevindinge. Tweedens was gepoog om die verband tussen die waargenome leierskapstyl en die vlak van outonomie, soos deur spanlede ervaar, te bepaal.

In die Suid Afrikaanse konteks, met die klem op globalisering en 'n demokratiese sosio-politiese fokus, is hierdie studie relevant veral in die lig van internasionale beste praktykstrewe op leierskap- en outonomievlak.

\section{Navorsingshipotese}

In die lig van die voorgaande literatuur is die volgende hipotese en postulate gestel:

- Daar is ' $n$ positiewe verband tussen selfbesturende (bemagtigende, transformasionele) leierskapsgedrag en outonomie.

- Daar sal een of meer statisties-beduidende kanoniese korrelasies wees tussen leierskap en outonomie metings.

- Daar is ' $n$ negatiewe korrelasie tussen direktiewe leierskap en outonomie.

\section{METODE}

\section{Steekproef}

Die hoofstudie is uitgevoer op ' $\mathrm{n}$ steekproef van 230 werknemers vanuit vier organisasies uit verskillende besigheidsektore. 'n Totaal van 56 leiers is beoordeel deur hul onderskeie spanne die outonomie- en leierkskapvraelyste te laat voltooi, ten einde ' $n$ meting van sowel die leierskapstyl as die vlak van outonomie te verkry. Die sektore verteenwoordig vervaardiging (chemies, voedsel en metaal) en inligtingtegnologie, wat spesifiek saamgestel is om ' $n$ verteenwoordigende stekproef te verkry vanuit verskillende organisasiekulture, bedryfskontekse, strategieë en internasionale mededinging.

\section{Meetinstrumente}

Met inagneming van die studiedoelwitte en hipotese is die Leierskapstrategievraelys van Manz en Sims (1991) en die Outonomievraelys van Gullowsen (1979) gebruik. Deelnemers is versoek om hul direkte bogeskikte se leierskapsgedrag, asook die vlak van spanoutonomie op 'n vyfpunt geankerde skaal te beoordeel.

\section{Leierskapstrategievraelys van Manz en Sims (1991)}

Die vraelys bestaan uit 81 items en fokus op die dimensies van "direktiewe", "transaksionele", "transformasionele" en "bemagtigings"-leierskap. Die Amerikaanse taalgebruik is egter vir "Suid-Afrikaanse" behoeftes aangepas. Skale vir meting van leierskapsgedrag sluit in intimidasie, toegekende doelwitte, instruksies en bevel, self-doelwitstelling, voorwaardelike materiële beloning, voorwaardelike persoonlike beloning, bevraagtekening van die status quo, visie, idealisme, stimulasie en inspirasie, aanmoediging tot self-probleemoplossing, selferkenning, self-denke, self-waarneming en self-evaluering.

Die vraelys is op ' $\mathrm{n}$ steekproef van 702 bestuurders in die verdedigingsindustrie in Amerika nagevors. Gebaseer op hierdie navorsing is 15 tipes leiergedrag geïdentifiseer, wat in ' $n$ vierstyl-leierskapmodel saamgevat is. Die betroubaarheidkoëffisiënte van die 15 skale het gewissel vanaf 0,62 tot 0,92 (Cox \& Sims, 1995)

\section{Outonomievraelys van Gullowsen (1979)}

Die outonomievraelys bestaan uit 35 items wat die vlak van outonomie aantoon soos deur die individu binne spanverband ervaar. Skale vir meting van groepoutonomie sluit in: beheer van doelwitte, prestasieregulering, besluite oor produksiemetode, taakdelegasie, groeplidmaatskap, spanleieraanstelling en besluitneming oor taakvoltooiing.

\section{Prosedure}

Spanleiers en groeplede is deur die onderskeie maatksappye se menslikehulpbronbestuurders persoonlik genader om deel te neem aan die studie. Respondente is uiteraard van vertroulikheid verseker deur slegs die spanleier op die vraelys aan te toon en om na voltooiing die vraelys in ' $n$ meegaande koevert te verseël en aan 'n sentrale kantoor te besorg.

\section{RESULTATE}

Om mee te begin is die vraelyste aan ' $\mathrm{n}$ faktor- en itemontleding onderwerp, ten einde die betroubaarheid en geldigheid daarvan vir Suid-Afrikaanse omstandighede te bepaal. Die doel met die faktorontleding was om die metingskale te toets teen die dimensies soos geïdentifiseer in vorige empiriese navorsing.

Die volgende prosedure is vir albei vraelyste gebruik. Die itemtellings is geinterkorreleer waarna die eigenwaardes van die interkorrelasiematriks bereken is. Volgens Kaiser (1961) se kriterium is daar soveel faktore onttrek as wat daar eigenwaardes groter as een was. ' $n$ Varimaksrotasie is gebruik om die matriks na ' $n$ eenvoudige struktuur te roteer. 
Faktorontleding van leierskapstrategievraelys van Manz en Sims (1991)
Die volgende itemladings is uit die faktorontleding verkry:

TABel 2

GEROTEERDE FAKTORMATRIKS VAN DIE LEIERSKAPSTRATEGIEVRAELYS

\begin{tabular}{|c|c|c|c|c|c|c|c|c|c|c|c|}
\hline \multirow[t]{2}{*}{ ITEMS } & \multicolumn{11}{|c|}{ ITEMLADINGS OP FAKTORE } \\
\hline & 1 & 2 & 3 & 4 & 5 & 6 & 7 & 8 & 9 & 10 & 11 \\
\hline \multicolumn{12}{|c|}{ 1. Persoonlike Erkenning } \\
\hline 70. & 0,84 & & & & & & & & & & \\
\hline 45. & 0,83 & & & & & & & & & & \\
\hline 21. & 0,82 & & & & & & & & & & \\
\hline 71. & 0,80 & & & & & & & & & & \\
\hline 12. & 0,77 & & & & & & & & & & \\
\hline \multicolumn{12}{|c|}{ 2. Self-probleemoplossing } \\
\hline 67. & & 0,72 & & & & & & & & & \\
\hline 64. & & 0,65 & & & & & & & & & \\
\hline 6. & & 0,59 & & & & & & & & & \\
\hline 76. & & 0,59 & & & & & & & & & \\
\hline 50. & & 0,56 & & & & & & & & & \\
\hline 18. & & 0,56 & & & & & & & & & \\
\hline
\end{tabular}

3. Instruksie en Bevel

41. 0,65

$60 . \quad 0,64$

$1 . \quad 0,64$

27. 0,62

$56 . \quad 0,62$

$11 . \quad 0,61$

$68 . \quad 0,59$

$19 . \quad 0,56$

$44 . \quad 0,52$

4. Toegekende Doelwitte

$75 . \quad 0,81$

$53 . \quad 0,71$

$10 . \quad 0,64$

$35 . \quad 0,63$

5. Idealisme/Visie

$34 . \quad 0,72$

$39 . \quad 0,58$

5. $\quad 0,46$

$9 . \quad 0,45$

$73 . \quad 0,44$

43. $\quad 0,42$

6. Self-Doelwitstelling

42.

7. Toevallige Teregwysing

17.

8. Materiële Vergoeding 
9. Aanmoediging tot self-beloning

37.

Faktorontleding van outonomievraelys van Gullowsen (1979) Met die faktorontleding van die outonomievraelys is nege faktore onttrek waarvan vyf grootliks ooreenstem met die faktore soos deur Gullowsen geïdentifiseer is. Faktore wat ooreenstem sluit in: selfdoelwitstelling, besluite oor produksiemetode, groeplidmaatskap, beheer oor groepleierskap en taakdelegasie.

TABEL 3

GEROTEERDE FAKTORMATRIKS VAN DIE ITEMS VAN DIE OUTONOMIEVRAELYS

\begin{tabular}{llllll}
\hline ITEMS & \multicolumn{5}{c}{ ITEMLADINGS } \\
\hline & 1 & 2 & 3 & 4 & 5
\end{tabular}

1. Selfdoelwitstelling

$1 . \quad 0,69$

$25 . \quad 0,61$

$29 . \quad 0,50$

2. Besluitneming oor Produksiemetode

10.

7.

24.

14.

3. Groeplidmaatskap

16.

26.

4. Beheer oor Groepleierskap

20 .

27.

34.

13.

5. Taakdelegasie

18.

Leierskaptrategievraelys van Manz \& Sims (1991) Tweedevlak faktorontleding

Subtellings is vervolgens geïnterkorreleer en aan ' $\mathrm{n}$ tweede faktorontleding onderwerp. Die verkreë faktormatriks is na ' $\mathrm{n}$ eenvoudige struktuur geroteer deur gebruik te maak van die Direct Oblimin rotasietegniek. Die faktormatriks verskyn in Tabel 4 .

Uit ' $\mathrm{n}$ inspeksie van Tabel 4 blyk dit dat die leierskapstrategievraelys slegs twee faktore opgelewer het:
TABEL 4

GEROTEERDE FAKTORMATRIKS VAN DIE SUBTELLINGS VAN DIE LEIERSKAP-STRATEGIEVRAELYS

\begin{tabular}{lcc}
\hline & FAKTOR I & FAKTOR II \\
\hline Subdimensies & \multicolumn{2}{c}{ Faktor lading } \\
Self doelwitstelling & 0,84 & \\
Persoonlike erkenning & 0,94 & \\
Visie en idealisme & 0,80 & \\
Aanmoediging tot & 0,83 & 0,48 \\
selfprobleemoplossing & & \\
Teregwysing & 0,57 & 0,29 \\
Daging van status quo & 0,30 & \\
Toegekende doelwitte & 0,66 & \\
Materiele vergoeding & 0,50 & 0,87 \\
Aanmoediging tot & 0,42 & 0,64 \\
selferkenning & & \\
Instruksie en bevel & & \\
Intimidasie & 0,32 & \\
\hline
\end{tabular}

Outonomievraelys van Gullowsen (1979) - Tweedevlak ontleding

Statistiek met betrekking tot outonomie lewer twee faktore op en word in Tabel 5 saamgevat. Faktor een sluit groepsgedrag rakende selfdoelwitstelling, beheer van produksiemetode en prosesse, werksregulering, leierskapbenoeming en buitestaander-beïnvloeding in, terwyl faktor twee gedrag rondom taakdelegasie, bepaling van werksure en taakindeling insluit.

TABEL 5

GEROTEERDE FAKTORMATRIKS VAN DIE SUBTELLINGS VAN DIE OUTONOMIEVRAELYS

\begin{tabular}{lcc}
\hline FAKTOR NAAM & \multicolumn{2}{c}{ FAKTOR } \\
\hline FAK01 & 1 & 2 \\
FAK04 & 0,71 & 0,36 \\
FAK02 & 0,54 & 0,33 \\
FAK08 & 0,90 & 0,46 \\
FAK03 & 0,23 & \\
FAK06 & 0,87 & 0,46 \\
FAK07 & $-0,32$ & \\
FAK09 & 0,27 & 0,94 \\
FAK05 & 0,19 & 0,34 \\
\hline
\end{tabular}

Die interkorrelasiematriks met betrekking tot die geroteerde faktore van sowel die leierskap as die outonomieresultate word in Tabel 6 weergee. 
TABEL 6

INTERKORRELASIES VAN LEIERSKAPS- EN OUTONOMIESKALE

\begin{tabular}{lrrrr}
\hline VERANDERLIKE & TOTFL1 & TOTFL2 & TOTF01 & TOTF02 \\
\hline TOTFL1 & 1,00 & & & \\
TOTFL2 & 0,20 & 1,00 & & \\
TOTF01 & 0,40 & 0,00 & 1,00 & \\
TOTF02 & 0,20 & $-0,05$ & 0,47 & 1,00 \\
\hline
\end{tabular}

FL - Leierskap

FO - Outonomie

Vir elk van die faktore is daar deur middel van ' $n$ iteratiewe itemontledingsprosedure ' $\mathrm{n}$ Cronbach Alfa betroubaarheidskoëffisiënt bereken. Tabel 7 dui die onderskeie betroubaarheidskoëffisiënte van elke faktor tesame met die getal items per faktor aan.

TABEL 7

BETROUBAARHEIDSKOËFFISIËNTE VAN DIE ONDERSKEIE SKALE

\begin{tabular}{lcc}
\hline SKAAL & BETROUBAARHEIDS- & AANTAL \\
& KÖ̈FFISIËNTE & ITEMS \\
\hline
\end{tabular}

\begin{tabular}{lrr} 
Leierskap & & \\
FL1 & 0,975 & 64 \\
FL2 & 0,873 & 4 \\
Outonomie & & \\
FO1 & 0,880 & 26 \\
FO2 & 0,711 & 8 \\
\hline
\end{tabular}

Kanoniese Korrelasie

Ten einde die getal statisties-beduidende kanoniese korrelasies te bepaal, is Bartlett se chi-kwadraattoets aangewend. Meer spesifiek het die kanoniese korrelasie ten doel om die korrelasie tussen leierskapstyle (as onafhanklike veranderlike) en vlak van outonomie (as afhanklike veranderlike) binne spanverband te bepaal deur die lineêre korrelasie van die onderskeie stelle veranderlikes op hierdie wyse te bepaal en daardeur 'n maksimum korrelasie tussen die twee stelle veranderlikes vas te stel.

\section{TABEL 8}

STATISTIESE BEDUIDENHEID VAN KANONIESE KORRELASIES

\begin{tabular}{cccccc}
\hline $\begin{array}{c}\text { EIGEN- } \\
\text { WAARDES }\end{array}$ & $\begin{array}{c}\text { KANONIESE } \\
\text { KORRELASIE } \\
\text { ONTTREK }\end{array}$ & $\begin{array}{c}\text { GETAL } \\
\text { EIGENWAARDES }\end{array}$ & $\mathrm{x}^{2}$ & $\mathrm{gv}$ & $\mathrm{p}$ \\
\hline 0,171765 & 0,414445 & 0 & 3,65054 & 4 & 0,000 \\
0,004174 & 0,031467 & 1 & 0,793 & 1 & 0,373297 \\
\hline
\end{tabular}

Tabel 8 dui die kanoniese korrelasies asook die resultate van Bartlett (1941) se chi-kwadraattoets aan. Laasgenoemde dui aan hoeveel kanoniese variate benodig word om die variansie tussen die twee stelle veranderlikes te verklaar. Die vereiste getal kanoniese variate verteenwoordig die kleinste getal eigenwaardes wat onttrek is sodat die toets vir die oorblywende eigenwaardes onbeduidend is. By nadere bestudering van Tabel 8 en Tabel 9 blyk uit die chi-kwadraattoetse vir die beduidenheid van die oorblywende eigenwaardes (Tabel 9) dat daar een kanoniese korrelasie is (Tabel 8) wat statisties-beduidend is $\left(x^{2}=36,5 ; \mathrm{p}=\right.$ $0,000)$. Hiervolgens is dit duidelik dat die onafhanklike kanoniese variaat TOTFL1 $(0,972)$ beduidend korreleer met die afhanklike kanoniese variaat OUTFL1 $(0,9998)$. Die onafhanklike veranderlike verklaar gemiddeld $47,3 \%$ van die $x$-komponent van die eerste variaat en die afhanklike veranderlike verklaar gemiddeld $64,3 \%$ van die $y$-komponent an die eerste variaat. Die korrelasie tussen die $x$ - en $y$-komponente is 0,414 .

Tabel 9

KANONIESE KORRELASIE-ANALISE VAN LEIERSKAP AS ONAFHANKLIKE VERANDERLIKE EN OUTONOMIE AS AFHANLIKE VERANDERLIKE

KORRELASIE VAN OORSPRONKLIKE METINGS MET KANONIESE VARIATE

EERSTE VARIAAT

Onafhanklike veranderlikes

TOTFL

0,972

TOTFL2

$-0,029$

Gemiddelde persentasie variansie verklaar

$47,3 \%$

Gemiddelde persentasie oortolligheid

$8,11 \%$

Afhanklike veranderlikes

OUTF1

$+0,539$

OUTF2

$+0,998$

Gemiddelde persentasie variansie verklaar

$64,3 \%$

Gemiddelde persentasie oortolligheid

$11,04 \%$

\section{BESPREKING}

Die primêre doel van die studie was die bestudering van die verband tussen selfgerigte leierskap en die vlak van outonomie soos deur die groeplede binne spanverband ervaar. Deur ' $n$ kanoniese korrelasie is aangetoon dat ' $n$ statisties-beduidende verband tussen die leier se bepaalde leierskapstyl en die span se gevoel van outonomie binne spanverband bestaan.

Die navorsing ondersteun ook vorige navorsing deur Van Staden, Scheepers en Rieger (2000), wat ' $n$ beduidende statistiese verband tussen interne lokus van beheer, outonomie en transformasionele leierskap aantoon.

Die kanoniese korrelasie bevestig dat individue binne spanverband ' $n$ groter mate van outonomie sal ervaar indien die spanleier ' $\mathrm{n}$ kombinasie van bemagtigings-, transformasionele, transaksionele en direktiewe leierskapstyle beoefen, teenoor ' $n$ suiwer direktiewe of voorskriftelike leierskapstyl.

Volgens die faktorontleding bestaan daar beduidende ondersteuning vir die Leierskapstrategievraelys soos deur Manz en Sims (1991) daargestel in ' $n$ poging om 'n vierstylleierskapmodel te verantwoord. Trouens, van die dertien faktore is elf beduidend verantwoord in die eerstevlak faktorontleding wat die geldigheid en betroubaarheid van die vraelys (ook binne Suid-Afrikaanse omstandighede) bo verdenking plaas.

Gebaseer op die tweedevlak faktorontleding, bestaan daar onvoldoende ondersteuning vir die vierfaktor-leierskapsmodel, soos deur Manz en Sims (1991) gepostuleer. Slegs twee faktore is uit die navorsing onttrek. Faktor 1 omsluit twee bemagtigingleiersgedrag van die oorspronklike model, soos deur Manz en Sims (1991) voorgehou, te wete selfprobleemoplossing en selferkenning. Dit sluit verder twee gedragtipes uit die transformasionele argetipe in, te wete visie en idealisme. Drie gedragstipes is voorts uit die transaksionele argetipe ingesluit, naamlik self-doelstelling, persoonlike erkenning en materiële vergoeding, terwyl teregwysing en toegekende doelwitte as direktiewe argetipeleiergedrag ingesluit is. Die tweede faktor bestaan uit twee gedragtipes verteenwoordigend van die direktiewe leierskapstyl, naamlik instruksie en bevel en intimidasie. Trouens, die navorsing dui veel eerder op die groepering van gedrag in 'n direktiewe leierskapstyl en 'n meer deelnemende of oorgangsleierskapstyl waarbinne die tradisionele transaksionele, transformasionele, bemagtigings- en enkele direktiewe gedrag saamgevoeg word. Hierdie groepering ondersteun die navorsing van Yukl (1989), Bass en Avolio (1993) 
en Sashkin en Rosenbach (1992) dat die onderskeid tussen transformasionele en transaksionele leierskap meer teoreties as empiries voorkom en in wese slegs ' $n$ kwalitatiewe anderse vorm van transaksie behels.

Die groepering van die kombinasie direktiewe, transaksionele, transformasionele en bemagtigingsgedragstipes in een faktor lok spekulasie uit. Die aanname word hieruit voorgehou dat, binne die steekproef se organisatoriese konteks, erkenning/beloning steeds as belangrike leierskapgedrag geag word en in wese steeds op ' $n$ gesagsafhanklike en transaksionele neiging dui. Andersyds beklemtoon dit die interverwantskap van die twee hoof leierskapstyle noodsaaklik vir organisasiesukses.

Insgelyks dui subtelling 7 (toevallige teregwysing) as deel van Faktor 1 op die integrale erkenning van gesag en die gepaardgaande behoefte aan prestasieterugvoer in die vorm van teregwysing. Hierdie benadering strook met die veronderstelde Suid- Afrikaanse vlak van ontwikkeling van beide werknemers en bestuurders met betrekking tot selfgerigte leierskap of outonome spanfunksionering. Die aanname word hieruit afgelei dat leierskap in die Suid-Afrikaanse konteks in 'n oorgangsfase verkeer tusssen die meer direktiewe en transaksionele na die meer transformasionele en bemagtigingsleiergedrag, terwyl daar steeds op die leier staatgemaak word tot voortdurende terugvoer en teregwysing ooreenkomstig prestasie gelewer.

Van waarde vir voortgesette navorsing is die leierskapvraelys wat veral op eerste orde basis oortuigende resultate gelewer het met betrekking tot itembetroubaarheid. Die groepering van response rondom metingskaal gemiddeldes lok voorts spekulasie uit en die aanname word gehuldig dat die studiesteekproef nie voldoende blootstelling of ontwikkeling beleef het met betrekking tot selfgerigte leierskap of spanoutonomie nie. Insgelyks kan die ontwikkeling van ' $\mathrm{n}$ unieke leierskapstyl bestaande uit gedrag vanuit die direktiewe, transaksionele, transformasionele en bemagtigings-leierskapdimensies ontluik, gegewe die gevolge van internasionale mededinging, toenemende sentralisasie as aanvaarbare "governance"-styl, vreeslose winsbejag en die pogings tot transaksionele verbintenis tussen werkgewer en werknemer met 'n hoofsaaklik monetêre grondslag. Die tradisioneel psigologiese kontrak tussen werkgewer en werknemer word derhalwe vervang met 'n oorwegend finansiële kontrak, waarbinne konkrete uitsette hoofsaaklik gemeet en vergoed word.

Dit wil voorkom asof leierskapstyle in suiwer vorm, soos byvoorbeeld direktiewe, transaksioneel, transformasionele en bemagtigingstyle in enkelvoudige keuse of praktyk, nie meer voldoen aan die eise van die moderne, internasionaal kompeterende onderneming nie. Gewis kan daar 'n verskuiwing plaasvind namate individuele en groepsuitsette en volwassenheid verhoog en leiers deur selfbesturende gedragsontwikkeling die groep hierbinne afrond en stimuleer. Industrie, en gevolglik die mensbestuur- en leierskomponent, beleef tans ' $n$ oorgangsfase vanaf die ou orde se beskermde era na 'n kompeterende dinamiese milieu met duidelik ' $n$ ander stel spelreëls, waarvan leierskap en spanfunksionering integrale komponente uitmaak.

Die tradisionele onderskeid tussen transaksionele en transformasionele leierskapstyle word nie deur die studiebevindinge ondersteun nie. Leiergedrag omsluit beide style, wat die navorsing van Mahoney (1990) en Sims en Cox (1995) ondersteun, naamlik dat leierskapstyl bepaal word deur die sosiale en ekonomiese konteks waarbinne 'n organisasie opereer. Die Suid-Afrikaanse organisatoriese konteks spreek gewis nog nie van ' $n$ selfgerigte en bemagtigende kultuur nie. Die resultaat hiervan is dat leiergedrag wissel vanaf direktiewe tot bemagtigsgedrag en dus in ' $\mathrm{n}$ fase van voortdurende herdefiniëring en evolusie verkeer.

Hierdie studie het teoriebou ten doel en is gewis nie sonder tekortkominge nie. Die mees waarskynlike is dat spesifieke leiergedrag, soos in die vierstyl-leierskapmodel en daaropvolgende vraelys vervat, nie noodwendig uitgeput en/of volledig is nie. Daar mag gevolglik bykomende leiergedrag geidentifiseer word wat van soortgelyke of selfs van meer belang mag wees.

Die studie verskaf in wese ' $\mathrm{n}$ beskrywende teorie en is nie ingestel op voorspellingsteorie nie, wat uiteraard die geleentheid bied vir vraelysgebruik in die bepaling van leiergedrag en die korrelasie met prestasie effektiwiteit.

\section{VERWYSINGS}

Adams, J. S. (1983). Wage inequities, productivity and work quality. Industrial Relations, 3, 9-16.

Arvey, R.D., \& Ivancevich, J.M. (1980). Punishment in organizations: A review, propositions, and research suggestions. Academy of Management Review, 5, 123-132.

Bandura, A. (1977). Social Learning Theory. Upper Saddle River, N. J.: Prentice Hall.

Bandura, A. (1986). Social Foundations of Thought and Action Upper Saddle River, N. J.; Prentice Hall.

Bandura, A. (1997). Self-efficacy: The Exercise of Control. New York: W. H. Freeman.

Bass, B. M. (1985a). Leadership: Good, Better, Best. Organizational Dynamics. Winter (pp. 26-40).

Bass, B. M. (1985b). Leadership and Performance beyond Expectations. New York: Free Press.

Bass, B.M. (1990). Bass and Stogdill's handbook of leadership: Theory, research and managerial applications (3rd ed.) New York: Free Press.

Bass, B.M. \& Avolio, B.J. (1993). Transformational leadership: A response to critiques, In Hunt, J.G., Baliga, B.R. Dachler, H.P. $\&$ Schriesheim, C.A. (eds.), Emerging leadership vistas. (pp. 2940). Lexington, MA: D.C. Health.

Burns, J.M. (1978). Leadership. New York: Harper \& Row.

Cox, J.F. \& Sims, H.P. (1995). Leadership and team citizenship behaviour: A model and measures. Referaat gelewer tydens simposium genaamd "Symposium on Work Teams" georganiseer deur die "University of North Texas".

Cummings, T.G. (1987). Self regulating work groups: A socio technical synthesis. Academy of Management Review, 3, 625-634.

Fisher, K. (1993). Leading Self-directed work teams, New York: McGraw-Hill.

Fleishman, E.A. (1973). Twenty years of consideration and structure. In E.A. Fleishman \& J.G. Hunt (Eds.), Current developments in the study of leadership. Carbondale, IL: Southern Illinois University Press.

French, J.R.P. \& Raven, B. (1959). The bases of social power. In D. Cartwright (ed.) Studies in social power. Ann Arbor: University of Michigan, Institute for Social Research.

Hackman, J.R. (1987). The design of work teams. Uit: J.W. Lorsch (Ed.) Handbook of organizational behaviour. Englewood Cliffs: Prentice-Hall.

Hackman, J.R., \& Lawler, E.E. (1971). Employee Reactions to Job characteristics. Journal of Applied Psychology, 55, 259-285.

Homans, G.C. (1958). Social behaviour as exchange. American Journal of Sociology, 63, 597-606.

Homans, G. C. (1961). Social behaviour: Its elementary forms. New York: Harcourt, Brace.

House, R. J. (1971). A Path-Goal Theory of Leader Effectiveness. Administrative Science Quarterly, 321-338.

House, R.J. (1977). A 1976 theory of charismatic leadership. In J.G. Hunt \& L.L. Larson (eds.), Leadership: The cutting edge. Carbondale, IL: Southern Illinois University Press.

House, R.J., \& Mitchell, T.R. (1974). Path-goal theory of leadership. Journal of Contemporary Business, 3, 81-97.

Mahoney, J.T. (1993). Psychological Origin of the LEA, (c) Management Research Group.

Kotter, J. P. (1990). Aforce for change; How leadership differs from management. New York: Free Press. 
Lawler, E.E. (1986). High involvement management. San Francisco: Jossey-Bass.

Luthans, F. \& Kreitner, R. (1985). Organisational behaviour modification and beyond. Glenview IL: Scott, Foresman.

Manz, C.C., \& Sims, H.P., Jr. (1990). SuperLeadership: Leading others to lead themselves. New York: Berkeley Books.

Manz, C.C., \& Sims, H.P. (1991). Super Leadership: Beyond the myth of Heroic Leadership. Organizational Dynamics. 18-35.

McGregor, D. (1960). The human side of enterprise. New York: McGraw Hill.

Meichenbaum, D. (1977). Cognitive-behaviour modification: An integrative approach. New York: Plenum Press.

Pasmore, L.A. (1988). Designing effective organisations: The sosio technical systems perspective. New York: John Wiley \& Sons.

Pearce, C.L. et al, (1995). Transactions, Transformers and Beyond: A multi-method analysis of leadership archetypes. Ongepubliseerde artikel. "College of Business and Management University of Maryland" - College Park.

Pearce, J.A., \& Ramlin, E.C. (1987). The design and activation of self regulating work group. Human Relations, 40. 741-782.

Sashkin, M. \& Rosenbach, W.E. (1992). A new leadership paradigm. (working paper).

Tichy, N. M. \& Ulrich, D. O. (1984). SMR Forum: The leadership challenge - a call for the transformational leader. Sloan Management Review, 26 (4), 59-68.
Thorenson, E.E. \& Mahoney, M.J. (1974). Behavioral self-control. Holt, Rinehart \& Winston.

Van Staden, J.F., Scheepers, J.M. \& Rieger, H.S. (2000). Lokus van beheer en transformasionele leierskap. Tydskrif vir Bedryfsielkunde, 26 (3), 8-14.

Veldsman, T.H. (1994). The philosophy behind self managing work teams. Ongepubliseerde Referaat.

Vroom, V. H. (1964). Work and Motivation. New York: Wiley.

Vroom, V.H., \& Jago, A.G. (1988). The new leadership: Managing participation in organizations. Englewood Cliffs, NJ: PrenticeHall.

Walton, R.E. (1985). From control to commitment in the workplace. Harvard Business Review, March-April, 77-84.

Walton, R.E., \& Hackman, J.R. (1986). Groups under contrasting management strategies. Uit: Goodman, P.S. \& Associates. Designing effective work groups. San Fransisco: Jossey-Bass, 168-201.

Webber, M. (1946). Essays in Sociology. New York: Oxford University.

Webber, M. (1947). The Theory of Social and Economic Organization. New York: Oxford University Press.

Wellins, S., Byham, C., \& Wilson, M. (1991). Empowered Teams. San Francisco: Jossey-Bass.

Yukl, G.A. (1989). Leadership in organizations (2nd ed.). Englewood Cliffs, NJ: Prentice-Hall 